\title{
PERLINDUNGAN KONSUMEN TERHADAP PELAKSANAAN PERJANJIAN LAYANAN PEMESANAN MAKANAN MELALUI OJEK ONLINE DI BANDAR LAMPUNG
}

Rissa Afni Martinouva, Fakultas Hukum Universitas Malahayati, Dina Haryati Sukardi dan Satrio Nur Hadi, Fakultas Hukum Universitas Mitra Indonesia; E-mail: dinaharyati@umitra.ac.id, rissa.afni.m@gmail.com, satrionurhadi@umktra.ac.id

\begin{abstract}
Abstrak
Fasilitas antar jemput dan pembelian makanan kini dibantu melalui pemesanan pada smartphone oleh konsumen. Penelitian ini difokuskan terhadap perjanjian pemesanan makanan melalui ojek online yang dinamai go-food. Terdapat beberapa konsumen yang mengeluhkan kerugian yang dialami terhadap perjanjian yang dilakukan pada pembelian pengantaran makanan melalui go-food. Melalui penelitian yuridis normatif ini, diketahui bahwa adanya kerugian yang dialami oleh salah satu konsumen driver go-food membuktikan bahwa perjanjian yang dilakukan tidak memenuhi unsur hak dan kewajiban, bertentangan dengan Pasal 4 UU No. 8 Tahun 1999 tentang Perlindungan Konsumen.
\end{abstract}

Kata Kunci: Perlindungan Konsumen, Perjanjian, Ojek Online

\begin{abstract}
Pick-up facilities and food purchases are now assisted by ordering on smartphones by consumers. This research is focused on food ordering agreements through online motorcycle taxis called go-food. There are several consumers who have complained about the suffered losses from the agreements made on food delivery purchases through go-food. Through this normative juridical research, it is known that the loss experienced by one consumer go-food driver proves that the agreement did not fulfill the elements of rights and obligations, contrary to Article 4 of Law no. 8 of 1999 about Consumer Protection.
\end{abstract}

Keywords: Consumer Protection, Agreements, Online Motorcycle Taxis

\section{PENDAHULUAN}

\section{Latar Belakang}

Transportasi merupakan sarana yang sangat diperlukan pada saat ini, dikarenakan transportasi dapat mempermudah pekerjaan dan tentunya membantu dalam rangka untuk memenuhi kebutuhan manusia. Transportasi sendiri meliputi tiga bentuk, yaitu : jalur darat, jalur laut, dan jalur udara. Mayoritas masyarakat lebih cendrung untuk menggunakan jalur darat dalam rangka untuk memenuhi kebutuhannya. Ketergantungan masyarakat untuk transportasi memang sangatlah tinggi, yang bertujuan untuk mempersingkat waktu perjalanan. Kesibukan dan aktivitas masyarakat untuk memenuhi kebutuhan sehari-hari turut menyita waktu dan energi. Aktivitas atau kesibukan yang menyita waktu dan menguras energi salah satunya yaitu pengantaran ketempat tujuan yang biasanya terkendala dengan macet. Jasa yang dapat dipakai untuk mengatasi stress ataupun kelelahan akbibat macet yaitu dengan menggunakan jasa dalam bentuk angkutan umum.

Penelitian ini mengartikan bahwa jasa yang disediakan oleh angkutan umum online telah dikenal dan dipercaya kemampuannya memberikan pelayanan berupa jemput antar konsumen dan mengantar makanan. Pelaku usaha yang membuka sarana angkutan 
umum online pada penelitian ini tentunya sudah terdaftar dan telah lulus melalui tahap perizinan pendirian secara legalitas.

Legalitas suatu perusahaan atau badan usaha yaitu merupakan unsur terpenting, karena legalitas merupakan jatidiri untuk melegalkan serta mengesahkan suatu badan usaha yang bertujuan untuk diakui oleh masyarakat. Angkutan umum online yang diyakini mampu mengemudi dengan baik dan telah lulus melalui seleksi kerja oleh pihak pengelolanya. Angkutan umum pada masa ini dimodifikasi cara pemesasannya dengan menggunakan teknologi aplikasi di smartphone penggunanya. Smartphone diartikan sebagai alat komunikasi pintar yang mampu digunakan untuk banyak aplikasi yang dioprasionalkan dengan cara instal atau mengaplikasikan program.

Smartphone adalah telepon genggam atau telepon seluler pintar yang dilengkapi dengan fitur yang mutakhir dan berkemampuan tinggi layaknya sebuah komputer. Smartphone dapat juga diartikan sebagai sebuah telephone genggam yang bekerja dengan menggunakan perangkat lunak Sistem Operasi (OS) yang menyediakan hubungan standar dan mendasar bagi pengembang aplikasi. Menurut David Wood, smartphone adalah handphone cerdas yang memiliki kelebihan dibanding alat telekomunikasi lainnya. Kelebihannya terlihat pada proses pembuatannya dan proses penggunaannya. ${ }^{1}$

Smartphone digunakan untuk membantu memesan sarana angkutan yang akan digunakan konsumen sebagai penumpang. Salah satu jenis angkutan umum berupa ojek online di Bandar Lampung yaitu Go-Jek. PT. Aplikasi Karya Anak Bangsa atau saat ini dikenal dengan go-jek adalah sebuah perusahaan yang bergerak di bidang angkutan untuk melayani melalui jasa ojek, perusahaan tersebut telah berdiri pada tahun 2010 di Jakarta oleh Nadiem Makarim.

Penumpang yang memiliki smartphone dapat dengan mudah dijemput dari tempat asalnya ke tujuan. Pemesanan yang dilakukan sering dikenal dengan angkutan umum online berupa ojek yang disediakan pelaku usaha.Angkutan online ini juga meayani pengantaran barang dan makanan. Seseorang dapat memesan dan memilih makanan mana yang dapat dipesan dengan memilih jenis layanan yang dinamai Go-food. Proses pemesanan alat angkutan ini yaitu melalui aplikasi di smartphone atau telepon selular android.Pengemudi ojek online yang akan memberikan layanan pengantaran makanan atau dikenal dengan go-foodhanya perlu meng-aktifkan layanan ojeknya pada aplikasi yang digunakannya sebagai mitra perusahaan pengelola. Konsep yang dibuat oleh perusahaan angkutan umum ini yaitu dengan memberikan honor/gaji kepada para pengemudi ojek online sebagai pekerja yang mengantar penumpang/ pengguna jasa yang memesan makanan melalui go-food. Fokus penelitian ini yaitu perlindungan terhadap layanan jasa pengantaran makanan yang sekaligus melakukan pembelian secara langsung menggunakan uang si pengantar makanan atau go-food.

Go-Jek mempunyai beberapa layanan, salah satunya adalah Go-Food. Layanan GoFood didalam aplikasi Go-Jek merupakan layanan pesan antar makanan yang didalam nya terjadi perjanjian antara penyedia layanan dengan pemesan. Perjanjian merupakan

1 https://www.maxmanroe.com/vid/teknologi/mobile-app/pengertian-smartphone. $\quad$ html diakses 16 Juli 2019. 
aspek yang penting untuk melakukan kegiatan bisnis.Dalam hukum perjanjian telah mengatur seluruh kegiatan dan ketentuan-ketentuan dengan tujuan bisnis berjalan lancar, tertib, serta aman sehingga tidak ada pihak yang merasa dirugikan.

Aplikasi yang diaktifkan untuk menerima pesanan jemput antar di tempat terdekat dari pihak pelanggan/penumpang yang akan memesan. Aplikasi pemesanan ojek online tersebut juga memperbolehkan pembatalan pemesanan. Pembatalan pemesanan yang dilakukan apabila belum dilakukan penjemputan serta menyesuaikan dengan alasan yang disepakati. Kesepakatan yang tidak dibatalan akan dilajutkan dengan melakukan perjanjian bertemu sesuai yang dituliskan tempat lokasi penjemputan pada aplikasi.

Kewajiban angkutan umum ojek online mengantar dan mendapatkan hak pembayaran dari pengguna jasa. Kewajiban pengguna jasa yaitu membayar sejumlah uang yang telah disepakati dan mendapatkan hak dijemput diantar ke lokasi yang telah disepakati pada aplikasi. Hak dan kewajiban akan menimbulkan suatu hubungan hukum antara pihak yang melakukan perjanjian. Dalam hubungan hukum khususnya mengenai kekayaan dan harta benda antara kedua kedua belah pihak yang memberi hak kepadayang satu untukmenuntut barangsesuatu dari yanglainnya, sedangkanorang yang lainnya ini diwajibkan memenuhituntutan tersebut. Pemenuhan hak dan kewajiban antara kedua pihak akan membetuk suatu hubungan hukum serta memberikan tanggungjawab teradap perjanjian yang disepakati.

Kesepakatan yang telah dilakukan dilanjutkan dengan mengkonfirmasi tempat lokasi yang lebih tepat agar langsung dapat ditemui lokasi penjemputan. Kegiatan pemesanan tersebut dilakukan dengan cara membuka peta pada layanan peta google/ googlemaps yang dipesankan. Terdapat beberapa konsumen yang mengeluhkan kerugian yang dialami terhadap perjanjian yang dilakukan pada pembelian pengantaran makanan melalui go-food. Seorang pengajar pada salah satu universitas swasta di Bandar Lampung berinisial AA mengemukakan dirinya mengalami kerugian saat melakukan pembelian melalui pemesanan makanan pada go-food. Kejadian yang dialaminya adalah nasi yang dibeli pada warung makanan XYZ tidak terdapat merek sesuai dengan yang dipesan (Hakim, 2018). Makanan yang telah diterima dan dibayar lalu diberi penilaian setelah itu saat dimakan tidak layak terhadap rasa. Rasa nasi yang dimakan setelah 20 menit kemudian telah berair dan seperti tidak layak konsumsi atau basi.

Pembelian yang dilakukan dikonsumsi untuk 6 (enam) orang. Karena sudah terlanjur dikonsumsi dan saling mengemukakan pendapat bahwa makanan yang dibeli tidak layak konsumsi. Konsumen AA merasa harus mengklaim kejadian tersebut, tetapi keadaan tersebut tidak mampu diklaim karena sudah terlanjur memberikan menyelesaikan pemesanan pada aplikasi. Penelitian ini akan menganalisis permasalahan yang seharusnya diantisipasi sebelumnya agar tidak merugikan konsumen sebagai pemesan pembeli layanan antar pembelian makanan melalui ojek online.

\section{Rumusan Masalah}

Keadaan tersebut membuktikan bahwa terdapat permasalahan yang harus dilakukan pembenahan pada perjanjian yang dilakukan. Berdasarkan uraian tersebut, maka permasalahan yang dibahas dalam penelitian ini adalah apa saja yang menjadi hak dan 
kewajiban para pihak yang melaksanakan perjanjian pemesanan makanan melalui ojek online dan bagaimana perlindungan konsumen pada perjanjian pemesanan makanan melalui ojek online.

\section{METODE PENELITIAN}

Metode Penelitian dalam penelitian ini, menggunakan pendekatan yuridis normatif dan yuridis empiris. Sebagai upaya mengumpulkan data yang dibutuhkan dalam penelitian, akan menggunakan dua cara pengumpulan data yaitu, studi kepustakaan dan studi lapangan. Analisis data yang dipergunakan dalam penelitian ini adalah analisis kualitatif dan penarikan kesimpulan dilakukan dengan metode induktif, yaitu menguraikan halhal yang bersifat khusus ke hal-hal yang bersifat umum sesuai dengan permasalahan yang dibahas dalam penelitian ini.

\section{PEMBAHASAN}

\section{A. Hak dan Kewajiban Para Pihak yang Melaksanakan Perjanjian Pemesanan Makanan Melalui Ojek Online}

Perjanjian yang dilakukan oleh para pihak saat melaksanakan pemesanan pembelian makanan melalui go-food telah memenuhi unsur syarat perjanjian. Syarat perjanjian pemesanan makanan melalui ojek online haruslah telah dipenuhi agar tidak terjadi halhal yang tidak diinginkan pada pelaksanaanya. Teori yang digunakan dalam penelitian ini adalah teori perjanjian dan perlindungan hukum konsumen.

Perjanjian akan menimbulkan hak dan kewajiban antara pihak-pihak yang harus dipenuhi berdasarkan yang diperjanjikan. Pemenuhan kewajiban bertentangan dengan wanprestasi yang tidak boleh dilakukan pihak-pihak yang melakukan perjanjian Wanprestasi yaitu tidak memenuhi kewajiban yang disepakati dalamperikatan. Salah satu perjanjiannya adalah perjanjian yang dibuat antara pemberi layanan dan konsumen, meliputi klausula-klausula yang telah disepakati untuk dilakukan atau dikerjakan oleh professional sebagai driver ojek online.

Keabsahan perjanjian dalam penyelenggaraan layanan pemesanan makanan melalui ojek online digunakan kriteria yang terdapat dalam ketentuan Pasal 1320 Kitab UndangUndang Perdata (KUHPerdata). Persyaratannya yaitu harus adanya:

1. Kesepakatan atau persesuaian kehendak. Kesepakatan perjanjian pemesanan pembelian makanan disertai dengan kesepakatan yang disetujui oleh para pihak. Persetujuan tindakan mengklik pesan sesuai barang dan jumlah yang harus dibayarkan oleh konsumen pada klausula online yang disediakan pada aplikasi go-jek;

2. Kecakapan para pihak merupakan syarat yang kedua dari perjanjian pengobatan tradisonal. Pasal 1320 KUHPerdata, menyebutkan bahwa orang-orang yang tidak cakapuntuk membuatsuatu perjanjianadalah: a. orang yang belum dewasa; b mereka yang ditaruh dibawah pengampuan; dan orang perempuan yang telah ditetapkan dalam undang-undang telah melaranng membuat perjanjian. Keadaan ini diikuti pada saat mendaftarkan diri menjadi pelanggan go-jek yang tidak membatasi konsumen pemesan. Konsumen pemesan hanya mendaftarkan nomor telepon yang digunakan. 
Dimungkinkan pendeteksian kecukupan umur melalui kepemilikan nomor telepon yang harus sudah memiliki Kartu Tanda Penduduk (KTP).

3. Suatu hal tertentu yang merupakan hal pokok ataupun obyek perjanjian berupa prestasi dan atau benda sebagaimana diatur dalam Pasal 1333 dan 1334 KUHPerdata suatu perjanjian haruslah mempunyai obyek tertentu. Suatu hal tertentu sangat penting kaitannya dalam pemesanan berupa barang yang dipesan dan diantar; dan

4. Syarat keempat perjanjian pengobatan tradisional adalah suatu sebab yang halal. Penyelenggaraan praktik pengobatan tradisional jika sudah disepakati maka harus mematuhi Pasal 1337 KUHPerdata suatu sebab adalah terlarang. Tujuan pemesanan terhadap objek makanan yang diperjanjikan memenuhi unsur halal yaitu makanan yang diperjanjikan tidak dilarang oleh undang-undang. ${ }^{2}$

Perjanjian pemesanan makanan melalui ojek online di atas, jelas bahwa jika dilakukan sesuai dengan prosedur yang ditentukan oleh undang-undang merupakan perjanjian yang sah dan mengikat para pihak driver ojek online dan pemesan makanan sebagai konsumen. Pada klausula perjanjian harus memberikan informasi yang jelas dan tepat kepada konsumen tentang tindakan layanan yang diberikan. Informasi yang diberikan hak-hak konsumen pada perjanjian di aplikasi harus jelas. Semua tindakan layanan pengantaran makanan dilakukan mulai dari memberikan kejelasan kondisi makanan dan jika terjadi hal-hal yang diluar keinginan para pihak makan perjanjian yang dilakukan bisa dibatalkan sewaktu-waktu. Bahkan pada saaat setelah dirasakannnya makanan yang didapatkan harus dapat diketahui bersama-sama dalam kondisi yang baik dan dapat diterima dalam keadaan sesuai harapan.

Penawaran yang telah dirundingkan oleh pihak konsumen dan pihak driver go-food akan melahirkan perjanjian. Perjanjian ini yang dinamakan sebagai pembelian pesan antar makanan.Unsur yang dipenuhi kejelasan para pihak, objek makanan dan sejumlah uang yang akan diganti oleh konsumen dengan cara dibayarkan kepada driver go-food. Perjanjian pembelian ini adalah sejenis pinjaman singkat yang dilakukan oleh konsumen. Konsumen meminjam sementara uang driver go-food yang akan langsung diganti setelah makanan sampai ke tangan konsumen. Perjanjian ini dapat dikonstrusikan sebagai perjanjian meminjam sementara uang driver go-food dan pembelian makanan yang juga diminta untuk diantar ke tangan konsumen. Diperlukan kepercayaan antara kedua belah pihak bahwa uang yang dipinjam sementara akan diganti sesuai dengan yang diperjanjikan bersama kesepakatan ongkos pengantaran. Konsumen juga harus dijaga kepercayaannya bahwa kondisi makanan yang dipesan akan sesuai dengan harapan. Memenuhi hak konsumen adalah kewajiban dari pelaku usaha yang telah melakukan perjanjian sebelumnya dengan konsumen.

Perbuatan hidup itumemberi petunjuk terhadap manusia bagaimana ia harus berprilaku serta bertindak didalam masyarakat. Peraturan-peraturan hidup seperti itu merupakan peraturan hidup bermasyarakat. Peraturan hidup bermasyarakat yang

\footnotetext{
2 Akbar, Arus Silondae dan Andi Fariana. (2010). Aspek Hukum dalam Ekonomi dan Bisnis. Jakarta: Mitra Wacana Media, h. 18
} 
bersifat mengatur serta memaksa dalam rangka menjamin tata tertib di dalam masyarakat merupakan peraturan hukum atau kaidah hukum. Hukum mengatur dan menguasai kehidupan berbangsa dan bernegara. Ilmu hukum mempunyai hakikat interdisipliner. Hakikat ini diketahui dari digunakannya berbagai disiplin ilmu pengetahuan untuk membantu menerangkan berbagai aspek yang dan berhubungan dengan kehadiran hukum di masyarakat. Uraian tersebut menerangkan terhadap kepatuhan yang harus diikuti oleh konsumen go-food namun juga pada layanan dan jasa yang diberikan harus mengikuti aturan yang berlaku.

Berdasarkan kasus yang ada pada kondisi yang diuraikan bahwa terdapat kerugian yang dialami oleh salah satu konsumen driver go-food maka telah terbukti bahwa perjanjian yang dilakukan tidak memenuhi unsur hak dan kewajiban. Hak yang didapatkan seharusnya seperti diuraikan pada Pasal 4 UU No. 8 Tahun 1999 tentang Perlindungan Konsumen huruf $\mathrm{b}$ yaitu hak untuk memilih barang dan/atau jasa serta mendapatkan barang dan/atau jasa tersebut sesuai dengan nilai tukar dan kondisi serta jaminan yang dijanjikan. Unsur hak yang tidak terpenuhi adalah hak konsumen mendapatkan kondisi makanan yang baik. Seharusnya pada form layanan perjanjian terdapat pemberian informasi kondisi barang yang akan dibeli antar oleh driver go-food. Pada perjanjian seharusnya juga memberikan wadah klaim yang dirasa perlu untuk menggambarkan kondisi barang yang diterima agar terpenuhinya kepuasan layanan pemesanan makanan melalui ojek online.

Arti jasa di antaranya adalah memberikan pelayanan yang dapat didasarkan pada prestasi dari penyedia jasa pelayanan yang menjamin mutu pelayanan yang tinggikarena ahli dan memiliki reputasi yang baik. 3Penyelenggaraan jasa layanan pengantaran makanan pada go-food harusnya mampu meningkatkan kualitas layanan yang lebih baik terutama pada aplikasi perjanjiannya agar memiliki reputasi yang baik.

\section{B. Bentuk Perlindungan Konsumen Terhadap Pelaksanaan Perjanjian Layanan Pemesanan Makanan Melalui Ojek Online}

Salah satu sumber utama konflik dan kekerasan di berbagai daerah adalah kondisi penegakan hukum di Indonesia yang sangat lemah. Ditambah lagi dengan berbagai bentuk diskriminasi dan marginalisasi dalam pengaturan social-ekonomi, politik, dan pemanfaatan sumber daya alam bahkan kehidupan budaya. Berbagai perasaan ketidakadilan dan ketidakpuasan umum pun berkecamuk dan meledak menjadi tragedi kemanusiaan yang sangat memilukan dan mengerikan. Konflik akan dapat dihindari dengan memberikan keadilan hukum secara tegas kepada pihak yang dirasa harus dilindungi. Penelitian ini membahas mengenai perlindungan hukum konsumen terhadap pelaksanaan perjanjian layanan pemesanan makanan melalui ojek online.

Alasan perlindungan hukum konsumen harus diberikan terhadap pelaksanaan perjanjian layanan pemesanan makanan melalui ojek online adalah agar hak dari konsumen dapat terpenuhi. Permasalahan hukum ditanggulangi bukan hanya pada saat

\footnotetext{
3 Asyhadie, Zaeni. (2014). Hukum Bisnis: Prinsip dan Pelaksanaan di Indonesia. Jakarta: PT Raja Grafindo Persada, Cetakan ke 8, h. 26
} 
terjadinya suatu masalah namun bisa berupa bentuk antisipasi terhadap bentuk kesepakatan agar melindungi para pihak.Penelitian ini menekankan pada kerugian yang dialami konsumen namun tidak mampu untuk diklaim sepenuhnya karena sudah terlanjur memberikan penilaian terhadap ojek online pengantaran makanan yang dinamai pada aplikasinya yaitu go-food. Kasus pada penelitian ini konsumen yang telah memesan, membayar dan memberikan penilaian serta menutup aplikasinya setelah ini baru menikmati makanan ternyata makanannya berupa nasi berkeringat dan basah. Kedaan nasi bungkus yang basi tersebut tidak mampu untuk diklaim oleh konsumen.

Keadaan yang dialami konsumen di atas membuktikan bahawa perlu adanya bentuk perlindungan konsumen terhadap pelaksanaan perjanjian layanan pemesanan makanan melalui ojek online.Kasus di atas juga dikhawatirkan bisa saja dialami oleh beberapa konsumen lainnya yang memesan dalam jumlah lebih banyak dan diperuntukkan bagi orang lain yang tidak termasuk si pemesan yang memakannya. Hal tersebut membuat kerugian yang sangat besar dan menimnbulkan kerugian formil yang seharusnya telah ada pemeriksaan secara khusus oleh driver goo-food dan mampu menjamin keadaan yang baik dari makanan yang dibeli dan akan diantar kepada pemesan makanan.

Perlindungan konsumenyang berasaskan manfaat, keadilan, keseimbangan, keamanandan keselamatan konsumen, serta kepastian hukum. Pasal 3 UU No. 8 Tahun 1999 tentang Perlindungankonsumen bertujuan : a. meningkatkan kesadaran, kemampuan dan kemandirian konsumen untuk melindungi diri; b. mengangkat harkat dan martabat konsumen dengan cara menghindarkannya dari ekses negatif pemakaian barang dan/atau jasa; c. meningkatkan pemberdayaan konsumen dalam memilih, menentukan dan menuntut hak-haknya sebagai konsumen; d. menciptakan sistem perlindungan konsumen yang mengandung unsur kepastian hukum dan keterbukaan informasi serta akses untuk mendapatkan informasi; e. menumbuhkan kesadaran pelaku usaha mengenai pentingnya perlindungan konsumen sehingga tumbuh sikap yang jujur dan bertanggung jawab dalam berusaha; f. meningkatkan kualitas barang dan/atau jasa yang menjamin kelangsungan usaha produksi barang dan/atau jasa, kesehatan, kenyamanan, keamanan, dan keselamatan konsumen.

Uraian asas tersebut membuktikan bahwa dibutuhkan kepastian hukum serta konsumen memiliki kemampuan dan kemandirian konsumen untuk melindungi diri agar terhindar dari kerugian-kerugian. Pasal 3 huruf b dan c juga perlu dilakukan oleh pihak pemberi layanan untuk menghindarkannya dari ekses negatif pemakaian barang dan/atau jasa. Konsumen perlu memilih, menentukan dan menuntut hak-haknya sebagai konsumen. Pelaku usaha juga perlu membenahi kontrak perjanjian online yang memastikan bahwa alur pemesanan sudah memberikan kenyamanan dan tidak menimbulkan kerugian sepihak terutama terhadap konsumen. Pelaku usaha menciptakan sistem perlindungan konsumen yang mengandung unsur kepastian hukum seperti pada Pasal 3 huruf d UU No. 8 Tahun 1999 tentang Perlindungan Konsumen.

Pasal 7 UU No. 8 Tahun 1999 tentang Perlindungan Konsumen juga menguraikan pada huruf a yaitu ada itikad baik yang harus dilaksanakan oleh pelaku usaha dalam melakukan kegiatan usahanya. Informasi yang jelas juga terhadap layanan yang 
diberikan yaitu pada Pasal 7 UU No. 8 Tahun 1999 tentang Perlindungan Konsumen huruf b. memberikan informasi yang benar, jelas dan jujur mengenai kondisi dan jaminan barang dan/atau jasa serta memberi penjelasan penggunaan, perbaikan dan pemeliharaan. Kondisi barang yang diantar oleh go-food yanglayanan pembeliannya diberikan oleh drivernya maka paling tidak harus ada keabsahan pada perjanjiannya yaitu menerangkan dan memastikan bahwa kondisi barang atau makanan yang diantar dalam konsidi baik serta dapat dipertanggungjawabkan. Hal tersebut tertuang pada Pasal 7 UU No. 8 Tahun 1999 tentang Perlindungan Konsumen huruf d. menjamin mutu barang dan ataupun jasa yang diproduksi dan ataupun diperdagangkan berdasarkan ketentuan standar mutu barang dan ataupun jasa yang berlaku.

Konsumen go-food juga seharusnya diberikan kesempatan untuk memastikan makanan yang dibeli melalui layanan tersebutlayak untuk dimakan hal ini diatur pada Pasal 7 UU No.8 Tahun 1999 tentang Perlindungan Konsumen huruf e yaitu memberi kesempatan kepada konsumen untuk menguji, danatau mencoba barang danatau jasa tertentu serta memberijaminan danatau garansi atasbarang yang dibuat danatau yang diperdagangkan. Setelah itupun harus berani untuk mengantisipasi dengan memberikan kompensasi jika nantinya makanan yangdipesan tidak sesuai dengan yang diperjanjiakan seperti diuraikan juga pada Pasal 7 UU No. 8 Tahun 1999 huruf f. memberi kompensasi, ganti rugi danatau penggantian atas kerugian akibat penggunaan, pemakaian dan pemanfaatan barang danatau jasa yang diperdagangkan dan g. memberi kompensasi, ganti rugi danatau penggantian apabila barang danatau jasayang diterimaatau dimanfaatkan tidaksesuai dengan perjanjian.Perlindungan konsumen dapat dibenahi melalui aplikasi perjanjian agar menjamin kepastian hukum saat dilakukannya transaksi pada pelaksanaan perjanjian layanan pemesanan makanan melalui ojek online oleh gofood.

\section{PENUTUP}

Terdapat kerugian yang dialami oleh salah satu konsumen driver go-food maka telah terbukti bahwa perjanjian yang dilakukan tidak memenuhi unsur hak dan kewajiban. Hak yang didapatkan seharusnya seperti diuraikan pada Pasal 4 UU No. 8 Tahun 1999 tentang Perlindungan Konsumen huruf b yaitu hak untuk memilih barang dan ataupun jasa dan untuk mendapatkan barang dan ataupun jasa tersebut sesuai dengan nilai tukar serta kondisi dan juga jaminan yang diperjanjikan.

Konsumen go-food juga tidak diberikan kesempatan untuk memastikan makanan yang dibeli melalui layanan tersebut layak untuk dimakan hal ini diatur pada Pasal 7 UU No.8 Tahun 1999 tentang Perlindungan Konsumen huruf e yaitu memberi kesempatan kepada konsumen untukmenguji, dan ataupun mencoba barang dan ataupun jasa tertentu serta memberi jaminan dan ataupun garansi atas barang yang dibuat dan ataupun yang diperdagangkan. 


\section{DAFTAR PUSTAKA}

Akbar, Arus Silondae dan Andi Fariana. (2010). Aspek Hukum Dalam Ekonomi dan Bisnis. Mitra Wacana Media, Jakarta.

Ali, Zainuddin. (2018). Filsafat Hukum. Jakarta: Sinar Grafika.

Asyhadie, Zaeni. (2014). Hukum Bisnis: Prinsip dan Pelaksanaan di Indonesia. Jakarta: PT Raja Grafindo Persada, Cetakan ke 8.

Bakti, U., Hairudin, H., \& Alie, M. S. (2020). Pengaruh Kualitas Pelayanan, Produk Dan Harga Terhadap Minat Beli Pada Toko Online Lazada Di Bandar Lampung. JURNAL EKONOMI, 22 (1), 101-118.

David Wood, Pengertian Smartphone, (https://www.maxmanroe.com/vid/teknologi/ mobile-app/pengertian-smartphone.html (Diakses 16 Juli 2019)

Hakim, L. (2018). Tinjauan Yuridis Perlindungan Hukum Terhadap Konsumen Pengguna Sistem Online Payment Point Bank. Jurnal Bina Mulia Hukum, 3(1), 104-112.

Kansil, C.S.T. dan Christine S.T. Kansil. (2011). Pengantar Ilmu Hukum Indonesia, Jakarta: PT. Rineka Cipta.

Kitab Undang-Undang Hukum Perdata

Muhammad, Abdulkadir. (2010). Hukum Perdata Indonesia. Bandung: Citra Aditya Bakti.

Prasetya, A. F. (2020). KEWENANGAN LEMBAGA NON-PENYIDIK DALAM MELAKUKAN PENYADAPAN. Jurnal Pro Justitia (JPJ), 1(1), 1-12.

Raharja, Satjipto. (2012). Ilmu Hukum, Cet.7. Bandung: Citra Aditya Bakti.

Sasongko, Wahyu. (2007). Ketentuan-Ketentuan Pokok Hukum Perlindungan Konsumen, Bandar Lampung: Penerbit Universitas Lampung.

SUKARDI, D. H., \& Herlambang, D. (2018). PENERAPAN PERJANJIAN KERJA ANTARA DIREKTUR DAN KARYAWAN TERKAIT DENGAN ASAS KEBEBASAN BERKONTRAK BERDASARKAN PASAL 1320 KITAB UNDANG-UNDANG HUKUM PERDATA. Journal Pranata Hukum, 53(9), 1689-1699.

Undang-Undang Nomor 8 Tahun 1999 tentang Perlindungan Konsumen 